\title{
When Unpaid Workers Need a Legal Status: Family Workers and Reforms to Labour Rights in Twentieth-Century France*
}

\author{
Manuela Martini \\ UFR Géographie Histoire Sciences de la Société, \\ Université Paris Diderot-Paris 7 \\ Laboratoire ICT-case courrier 700I, Bâtiment Olympe de Gouges, \\ I7, rue Jean-Antoine de Baiff, 7520s Paris Cedex 13, France
}

E-mail: manuela.martini3@gmail.com

\begin{abstract}
AвSTRACT: In the second half of the twentieth century small family businesses were still widespread in France. An important reason for this resilience was the share of unpaid work performed by kin in producing for the market. The unpaid work of family members in a range of craft and commercial family businesses particularly by spouses, sons, and daughters - contributed to both the survival of the businesses and the well-being of the families, as is testified to in numerous sources, albeit statistically undocumented. Although social rights in France are considered to be some of the most advanced in Europe, the French Parliament was extremely slow to define the legal status of these family workers. It was not until 1982 that a law was finally enacted to bestow occupational status on collaborating spouses and to define a procedure optionally to register this unpaid work and to secure social security benefits for those carrying it out. This article focuses on the process that led to a new definition of the demarcation between the marital duty to assist, and work that exceeds this moral and legal obligation, thus creating a legal right to be compensated. Two empirical perspectives, involving an analysis of the reasons behind the shifting position of trade associations on this issue, and an assessment of the influence of long-standing gendered institutions, such as marital authority, on the formal and informal rules
\end{abstract}

\footnotetext{
* An earlier version of this article was presented at the 9th European Social Science History Conference at Glasgow University, I I-I4 April 20I2. I would like to thank the participants at the session "Working with Kin: Unpaid Work, Apprenticeship and Kin's Labour in Family Business", which I co-organized with Anna Bellavitis, for their comments and suggestions, as well as Aad Blok, the anonymous referees of the $I R S H$, and all the participants and discussants at the workshops I organized with Anna Bellavitis in Paris (20II) and Rouen (20I2) as part of the "Travail en famille, travail non rémunéré" research programme supported by the Laboratoire ICT - Université Paris Diderot, the Laboratoire GRHIS - Université de Rouen, and the École française de Rome. Regarding any mistakes or omissions, the usual disclaimer applies.
} 
regulating family business are used to illustrate this slow and tortuous process of acquiring occupational rights for family workers.

The overlap between the domestic unit and the production unit the household economy - is an important issue in historical studies of European societies. In the literature, the household economy is studied mostly in the context of historical periods preceding industrialization. ${ }^{\mathrm{I}}$ Its development in modern times is mentioned, but little studied.

Yet family business in the twentieth century was, as in the past, the dominant form of economic organization in western Europe. Recent studies conducted by the Family Business Network have quantified the number of family businesses not measured in public statistics and concluded that they can no longer be regarded as marginal or residual. According to these studies, in 2007, for example, 83 per cent of French enterprises were family businesses, accounting for around one-half of total employment. ${ }^{2}$ Although not all family businesses are of equal size and some family businesses, especially those listed on the stock market, employ large numbers of workers and operate more like capitalist and managerial firms than early modern households, these large family businesses constitute only a very small, albeit economically powerful, minority. In France 84 per cent of family businesses employ fewer than Io workers. In all these instances household and family businesses presumably interact with one another very frequently. ${ }^{3}$ The unpaid work

I. Amy Louise Erickson, Women and Property in Early Modern England (London [etc.], 1993); Maria Agren and Amy Louise Erickson (eds), The Marital Economy in Scandinavia and Britain, I400-I900 (Aldershot [etc.], 2005).

2. A 2007 study by the Family Business Network Monitor was quoted in a 2009 report by Olivier Mellerio to Hervé Novelli, Secretary of State for Commerce, Craft, and Small Business, on "family business succession": "Rapport à Hervé NOVELLI, Secrétaire d'État chargé du Commerce, de l'Artisanat, des Petites et Moyennes Entreprises, du Tourisme, des Services et de la Consommation", Transmission de l'entreprise familiale (Paris, 2009), http://www.asmep-eti.fr/ wordpress/wp-content/uploads/2013/05/Rapport-Mellerio.pdf [hereafter Rapport Mellerio]. According to this report, family businesses account for 73 per cent of all businesses and 52 per cent of jobs in Italy (the job share is 44 per cent in Germany and 4I per cent in Finland); in the Netherlands and Great Britain the shares of family businesses are 6I per cent and 65 per cent respectively, and family businesses account for just one-third of jobs in both countries. For a definition of a large family business see Renato Tagiuri and John A. Davis, "Bivalent Attributes of the Family Firm”, Family Business Reviere, 9 (1996), pp. 199-208: “An organization where several members of the extended family influence the management of the company through ties of kinship, management positions or capital ownership rights", quoted on p. 53 .

3. See, for example, Céline Bessière and Sibylle Gollac, "Le silence des pratiques. La question des rapports de genre dans les familles d'indépendants", Sociétés et représentations, 24:2 (2007), pp. $43-58$. 
of women and of other members of the family is often crucial to the constitution, survival, and development of these small and very small businesses.

How many people are involved in this type of activity within small enterprises? What professional status characterizes them across different economic sectors? Until World War II the only available data were qualitative observations, and even after the war they were very unequal, and probably underestimated the actual numbers. ${ }^{4}$ In France family workers were identified in the 1954 population census, but they were no longer recorded in 1968.5 They were once again counted in the 1975 census, but family workers in agriculture, for instance, were estimated to number a total of 506,000 (including 377,100 women), even though in I97 I a Ministry of Agriculture estimate based on a more extensive definition of the rural working population, and including people working not only full-time but also part-time on farms, put the number of family workers at quadruple this figure. The number of people who were not heads of farms but "regularly" worked on farms totalled 417,523 men and I,374,66I women in the I969-1970 "agricultural season" (campagne agricole). ${ }^{6}$

Like other precarious and intermittent employment in a family business, the work of kin, and particularly women's work, lacks visibility and might indeed be completely "invisible". Nevertheless, at the end of the I930s the ILO considered the contribution to family businesses so significant that, beginning in 1937, it was considered to meet the threshold for the International Classification of Status in Employment (ICSE) and appeared in the statistical table on the active population (gainfully occupied population, distribution by industrial status). Despite the fact that these boxes remained

4. For a detailed analysis of the reasons that led to the number of family workers being underestimated, see Françoise Battagliola, Histoire du travail des femmes (Paris, 2008).

5. INSEE, Recensement général de la population de 1962, Résultats du sondage au I/20 pour la France entière: ménages, familles (Paris, 1964). In 1962 female family workers numbered I,234,040 (of whom 943,888 were employed in agriculture), i.e. I8.7 per cent of the active population (I, pp. 70-7I). The number of male family workers was $45 \mathrm{I}, 060$ (including 394,320 in agriculture), i.e. 3.6 per cent of the male active population. In 1954, according to the census statistics, the number of male family workers was $784,3 \mathrm{I} 3$, with the corresponding number of females being I,727,004; ibid., pp. 68-71.

6. Ministère de l'agriculture et du développement rural, Direction générale de l'administration et du financement, "Service central des enquêtes et des études statistiques", Recensement général de l'agriculture 1970-7I, Résultats France entière, V, Population des exploitations agricoles (Paris, I972), p. 17. In order to calculate the number of family workers I subtracted the number of female and male heads of the farms from the active female and male population living and working on the farms. In this census "Farmworkers for the 1969-1970 crop year include anyone who has performed regular, even if minimal, work on the farm during the period. [However], casual work [harvesting] by family members who do not live on the farm is excluded", p. Io. 
empty for many countries, the "unpaid family workers" category continued to appear in every ICSE update until the final update in the I990s. ${ }^{7}$

Besides the statistical tracking, this important decision was no doubt frequently discussed in the corridors and meetings of the ILO. ${ }^{8}$ At the end of a major investigation that began in 1936, Marguerite Thibert, a militant feminist and ILO official in charge of women and child labour issues, drafted a report published two years later with a subtitle: "A Contribution to the Study of the Status of Women", that does justice to the intellectual openness and analytical skills of this international expert on female employment. ${ }^{9}$ In the section on "Female employment problems related to the civil and political status of women", she demonstrates her grasp of a major limitation in recognizing productive female labour that at the time especially affected married women:

Another disability imposed in several countries on women married under the regime of the "community of property" is that of having no legal title to remuneration for a job done in their husband's employment. The disability exists in French law for instance, the revenue authorities having disputed the right of a woman who helped her husband in his business to deduct her wages from his earnings. A similar situation arises under other laws of the same kind, notably in some of the United States of America. ${ }^{\circ}$

7. See ILO, Yearbook of Labour Statistics (Geneva, 1938). Note that this was the second yearbook. See ILO, Yearbook of Labour Statistics, Retrospective Edition on Population Censuses (Geneva, 1990). Here a family worker is defined as "a person who works a specific amount of time (at least one-third of normal working hours), without pay, in an economic enterprise operated by a related person living in the same household”, p. xxxv. The ILO's interwar statistics for north-western Europe include data for Germany, Austria, Belgium, and Italy, but not for the United Kingdom, France, Spain, Norway, the Netherlands, and Denmark; (the other countries for which data are available, but difficult to cross-compare, include Hungary, Czechoslovakia, and Estonia); ILO, Yearbook of Labour Statistics [1937-1938]. After World War II most countries provided data, though they were generally not comparable.

8. For this issue, the years around $1935-1937$ were a turning point, as appears from a comparison of a report published by Marguerite Thibert in I93 I: Bureau international du travail, $L a$ réglementation du travail féminin (Geneva, I93 I), ch. I I, "Les problèmes du travail féminin en connexion avec le statut civil et politique des femmes", with that appearing in 1938 . See, too, BIT, L'organisation internationale du travail et le travail des femmes (Geneva, 1926); in this report the three main issues relating to women's work were: night work, maternity leave, and occupational health.

9. For Marguerite Thibert's biography see Françoise Thébaud, "Réseaux réformateurs et politiques du travail féminin. L’OIT au prisme de la carrière et des engagements de Marguerite Thibert", in Isabelle Lespinet-Moret and Vincent Viet (eds), L'Organisation internationale $d u$ travail. Origine, développement, avenir (Rennes, 20I I), pp. 27-37; Céline Schoeni and Nora Natchkova, "L’Organisation internationale du travail, les féministes et les réseaux d'expertes. Les enjeux d'une politique protectrice (1919-1934)", in Lespinet-Moret and Viet, L'Organisation internationale du travail, pp. 39-52.

Io. ILO, The Law and Women's Work: A Contribution to the Study of the Status of Women [Studies and Reports, Series I (Employment of Women and Children), 4] (Geneva, 1939), p. 556. 
As a Frenchwoman, she was referring to her country, where, on the eve of World War II, small firms and independent shops benefited greatly from the work of spouses, as they had done throughout the preceding century after the Civil Code underlying this civil legislation had been conceived in $1804 .{ }^{\text {II }}$ She was most likely thinking of small family production units when she wrote these lines underscoring the lack of recognition of the occupational status of female labour. Her voice was that of a small minority. The contribution of a collaborating spouse was difficult to determine at the time, for the actors themselves and also for legal professionals, since it involved several areas of civil law: marriage, tax, and family. ${ }^{22}$

Thus, despite reflections leading to very precise framings of this issue, it was not until 1982 that France implemented a law to define the condition and status of these predominantly female workers, and their rights deriving from working in a family business. The 1982 law adopted a liberal approach in its attempt to address the most pressing issues concerning the role of the business owner's spouse, and it did not require collaborative activity to be mandatorily declared.

The law's limitations, which sociologists and legal experts highlighted as soon as it was enacted, ${ }^{\mathrm{I} 3}$ were most flagrantly illustrated by its weak effect on family business practices. The institutional response to this lack of factual efficiency had to wait for a comprehensive revision of small business regulations. Almost a quarter of a century later, the Dutreuil Law, enacted in 2005 "in favour of SMEs", provided an opportunity to reform the 1982 law and to mitigate the most obvious of these limitations. After years of debate, the 2005 law finally introduced an obligation to declare the status of a spouse in accordance with the 1982 law: associate, employed, or collaborating spouse. ${ }^{\mathrm{I}}$ As this can be considered a milestone in the history of the condition of collaborating spouses in productive activities, it is worth retracing the historical path that brought this issue to the forefront and gave

I I. Battagliola, Histoire du travail, p. Iо. See, too, Laura L. Frader, "Définir le droit au travail: rapports sociaux de sexe, famille et salaire en France aux XIXe et XXe siècles", Le mouvement social, I84 (1998), pp. 5-22; idem, Breadwinners and Citizens: Gender in the Making of the French Social Model (Durham, NC, 2008).

I 2. Several jurists have stressed this issue, including Didier Martin, Le conjoint de l'artisan ou $d u$ commerçant. Statut professionnel, fiscal, social, matrimonial et successoral (Paris, 1984) and Anne Karm, L'entreprise conjugale (Paris, 2004).

I3. Bernard Zarca, "Indépendance professionnelle, relations entre les sexes et mobilisations collectives", Sociétés contemporaines, I6 (1993), pp. 77-109.

I4. The law was enacted while Dominique de Villepin was prime minister of a right-wing coalition and during President Jacques Chirac's second five-year term. See Title III, art. I 2 of Law no. $2005-882$ of 2 August 2005 in favour of small and medium enterprises (I) Journal Officiel de la République (JORF), no. 179, 3 August 2005, p. I2639, which states that this norm will be part of Title II of Book I of the Commercial Code (Code du commerce). 
it a visibility in the eyes of social decision-makers and actors. This path also has a broader dimension as it deals with the connection between the private and professional spheres that is especially prevalent in craftwork, where it has persisted throughout history to this day. ${ }^{\text {IS }}$

The reasons for the late and limited recognition of the role of craft family workers (primarily spouses, sons, and daughters) can be illustrated through an analysis of different and competing legal and political conceptions that emerged, particularly beginning in the mid-I960s, about the productive work of the helping spouse. This empirical perspective will show how this prolonged process reflects the slow transformation of generational and gender relations in families.

The normative conception of the family included in the Napoleonic Code of I 804 left little room for the emergence of contractual relations, especially between spouses. According to the Civil Code of I 804 the husband is the head of the family and the administrator of any joint property and earnings. ${ }^{16}$ Another institution specific to the Napoleonic Code formed the pillar of this gendered construct: the institution of marital authority whereby the wife is obliged to obtain authorization from her husband before taking any public action. ${ }^{17}$ As the enterprise was neither defined nor covered by the Commercial Code of I806, which regulated the actions of individual entrepreneurs only, family workshops were subject mainly to civil law norms that defined both economic and moral obligations. ${ }^{8}$

The existing literature on family history and gender history in France has focused mostly on the first two aspects of this normative construct. This article will specifically address a third obligation outlined in the Civil Code and that concerns the nature of matrimonial relations: the spousal duty to assist. This framework considerably held back the establishment of contractual relations between spouses; arguments tied to the duty to

I 5. The status of unpaid family workers who are kin has not yet been recognized by law. Sons and daughters, fathers, mothers, and siblings of the head of the family business are considered a residual group, less important in quantitative terms than spouses. See, for example, Médiateur de la République, "Question écrite no. 08242 de M. Philippe Marini (Oise - UMP)", JORF, Senat, I4 May 1998, p. I 526.

16. Frader, Breadwinners and Citizens, passim. See, too, André Burguière, "La famille comme enjeu politique (de la Révolution au Code civil)", in Centre de recherche interdisciplinaire de Vaucresson, La famille, la Loi, l'Etat de la Révolution au Code Civil (Paris, 1989); Jacques Commaille, Pierre Strobel, and Michel Villac, La politique de la famille (Paris, 2002). For more bibliographical references see, too, Karen M. Offen, "French Women's History: Retrospect (1789-1940) and Prospect", French Historical Studies, 26 (2003), pp. 727-767.

17. For a very general overview that extensively covers France, see Nicole Arnaud-Duc, "Les contradictions du droit", in Geneviève Fraisse and Michelle Perrot (eds), Histoire des femmes en Occident, IV, Le XIXe siècle (Paris, I991), pp. 87-I 16, I09-I I2.

I8. Karm, L'entreprise conjugale, pp. 20-33. 
provide mutual aid were most frequently invoked to deny the legitimacy of contractual relations between spouses, especially once the barriers surrounding marital potestas fell.

\section{DEBATES ON MARITAL RELATIONSHIPS IN FAMILY BUSINESS}

The nature of family ties, which at a very intimate level forms the basis of relationships between spouses in households and family businesses, is at the crux of arguments put forward by legal experts. The particular relations that characterize marriage generate arguments that are most often made on "moral" grounds, and that point to obligations of mutual aid within the marriage and family as guaranteeing the smooth functioning of economic activities. Discussion on defining economic relations within a household and family business was reopened in the mid-r96os with legal and political arguments emphasizing the market value of this work and the need to create contractual relations among family members involved in productive activity. ${ }^{19}$

Our aim is, first of all, to follow the main institutional steps preceding and accompanying the debate opposing these conflicting visions of marital and interfamilial relationships within family businesses. This longterm historical analysis will allow us to catch the apparently contradictory dynamics of the law enacted in 1982 and which defined the collaborating spouse status, and to identity its achievements and the resistance to which it gave rise. Undoubtedly, the moral arguments directed at a contractual definition of family relationships by jurists, politicians, and social actors in the second half of the twentieth century were rooted in the nineteenth century, when, as we have seen, matrimonial and family law was defined.

One of the most important consequences of the subordination of other family members to the head of the family is that the fruits of any joint labour were considered inseparable from the workshop's assets (also the family's joint assets) and subject to the direction of a paterfamilias acting for the common good. ${ }^{20}$

Beginning in the mid-nineteenth century these workshops began to interact with productive systems that, for the first time, included much

19. See, for example, Arnaud-Jean Raynal, L'entreprise familiale: psychologie, gestion, fiscalité (Paris, 1963); Raymond-François Le Bris, La relation de travail entre époux (Paris, 1965). See Ministère du commerce et de l'artisanat, Secrétariat d'Etat à la condition féminine, Situations des femmes dans les secteurs du commerce et de l'artisanat, rapporteur, M.T. Claudé, mai 1976 (Paris, 1976) [hereafter Rapport Claudé], and Comité du travail féminin, Rapport sur les conjointes de non salariés exerçant une activité professionnelle dans l'entreprise familiale. Actualités du travail des femmes (Paris, 1979).

20. For more on French sociology's holistic conception of the family and the family's role in the preservation or "reconstitution" of the social fabric, see Commaille, La politique de la famille, pp. 22-23. 
more complex, mechanized, and concentrated units than in the preindustrial past. The novel and disruptive effects of these changes shaped new forms of labour organization, but the changes also coexisted with old production conditions and social institutions. Contrary to what researchers and analysts of the social consequences of the industrial revolution had anticipated, industrial concentration in France was a gradual and very uneven process in some areas. The average number of employees by industrial unit throughout the industrial sector as a whole totalled 6 in 1906, 8.7 in $192 \mathrm{I}$, and 10.8 in $193 \mathrm{I.}{ }^{21}$ In 1926, 52 per cent of the working population was employed in businesses with fewer than 20 employees; in 1962 and 1966 the corresponding figure was 30 per cent. Since the mid-I970s the trend has actually strengthened: in 2005, these businesses employed 37.6 per cent of the working population. ${ }^{22}$ The developments help to explain the resurgence in the twentieth century of seemingly outdated forms - that had in fact never completely disappeared - of definitions of relations among family business members.

In the mid-nineteenth century, a majority of the representatives that were about to vote on the social and tax laws of the Third Republic were of the same opinion as Frédéric Le Play, founder of the Social Economy Society: "Our most fatal error is to allow State encroachment to disrupt the authority of the family father [...] the error is to submit the household, workshop, and family personnel to the authority of legislators, bureaucrats, and their agents." ${ }^{3} 3$ Thus, in line with the safeguard principle that Karl Marx called "the sacred institution of the family" at the time, many rejected any interference in family workshops. In the words of Marx:

So long as Factory legislation is confined to regulating the labor in factories, manufactories, etc., it is regarded as a mere interference with the exploiting rights of capital. But when it comes to regulating the so-called home-labor, it is immediately viewed as a direct attack on the patria potestas, on parental authority. ${ }^{24}$

21. Michel Lescure, PME et croissance économique: L'expérience française des années 1920 (Paris, 1996), p. I5.

22. Edmond Malinvaud and Michel Didier, "La concentration de l'industrie s'est-elle accentuée depuis le début du siècle?”, Économie et Statistique, 2:2 (1969), pp. 3-10, 7; Rapport Mellerio, p. 37.

23. Charles Badiou, Essai sur la réglementation du travail dans l'atelier de famille (Lyon, 1907), p. 44 .

24. Karl Marx, Le Capital, Livre I, t. 2, trad. J. Roy, I872-1875 (Paris, 1973), p. I67. English translation: Capital: A Critique of Political Economy, I: The Process of Capitalist Production, translated from the 3 rd German edition by Samuel Moore and Edward Aveling, edited by Friedrich Engels, revised and amplified according to the 4th German edition by Ernest Untermann (Chicago, I 909), Book I, Part 4, ch. I5, "Machinery and Modern Industry", p. 230. Like many other social economists, he was referring mostly to the work performed by children. 
As is the case for relatives actively involved in family businesses in France today, at that time a family member's or spouse's unpaid, regular work was recognized solely through a family's internal convention and transaction, subject to the goodwill and intentions of the head of the household.

Alternately, it could be recognized through litigation and conflict brought about by individual demands to be compensated for labour provided in market production. In some cases craftsmen based these claims on the existence of institutions created for farmers, such as "deferred salary", a form of compensation for unpaid work on family property created in I939, or on concepts of civil and commercial law, such as "unjust enrichment".

Deferred salary in particular was an important legal development in this area: an unpaid son or daughter's right to claim an additional share of the paternal inheritance in the event of the father's death. This legal provision is especially interesting for three reasons. The first is that it was added to the group of measures affecting the family that were voted into law on 29 July I939 (two months before the outbreak of World War II on 3 September) and which have since unofficially been called the "Family Code". ${ }^{25}$ Indeed, in a way, establishing the right to a debt to be paid after the death of the head of the family involves ruling on the conditions determining the continuity of both the farm and the family. It is no coincidence that this law was part of a series of measures taken to promote the cohesion of this social institution that, for over a century, many had feared would dissolve. ${ }^{26}$ The second reason is that the law introduced the possibility of taking into account the unpaid work performed by the spouse of a son working on the step-family's farm. This was one of the first forms of recognition of the unpaid work of women in the context of production activity.

The third reason is that the link between an unpaid child and his or her ascendant was defined as a contract, a "work contract with a deferred salary". Some ambiguity remained since, a little further on, article 73 specified that it was a contract in name only since it did not have any of the attributes of a work contract (especially in terms of social rights) given that it linked two members of the same family, and more specifically a child to his or her ascendant (moreover, it was only in this case that the right could be claimed). ${ }^{27}$

25. Christophe Capuano, Vichy et la famille. Réalités et faux-semblants d'une politique publique (Rennes, 2009); Anne Cova, Maternité et droits des femmes en France (XIXe-XXe siècles) (Paris, 1997), pp. 365-392; Michel Chauvière and Virginie Bussat, Famille et codification: le périmètre du familial dans la production des normes (Paris, 2000), pp. 66-76.

26. Capuano, Vichy et la famille, p. 36.

27. The aim of this law was to avoid young farmers leaving the family farm. See Léon Rival, Le contrat de travail à salaire différé en agriculture: son but, ses bénéficiaires, barèmes de salaires, formules d'actes (Paris, I942), pp. I3-I4. 
A key feature of these provisions is that they create very strong links between unpaid work within a family enterprise and the distribution of assets when they are bequeathed after the death of the head of the family business. For historians, there is a clear parallel with ancient informal provisions for the bequeathing of property in farm and craft families. The overlap between family assets, individual assets, and capital from family holdings could hardly be more embedded. This type of arrangement prevailed for a long time, but it began to change around the end of the I960s, when a growing number of people realized that the marriage bond might dissolve even before death, due to divorce or separation. Alternatively, there might simply have been a realization that, upon retirement, the labour-force withdrawal of two working partners of the same age collaborating in the same business would leave no trace of the lifetime's work of one of the two - the husband would receive a pension for his professional activity but his spouse would not.

Debate over these issues became widespread in the I960s, as we will show more precisely below, but criticism had begun much earlier. The arguments put forward could draw on changes in doctrine and case law that occurred during the interwar period. As we have seen in relation to the deferred salary in agriculture, the vision of the complete embedding of household and economic activity, with strict gender and generational hierarchies, drew criticism from reformers, including jurists, in the interwar period. ${ }^{28}$ The abolition in I 938 of the married woman's juridical minority was part of this new attitude toward women's rights and opened new avenues. Jurists started to ponder the fundamental question of whether paid contracts between spouses were legally valid. Was it possible to conceive of a commercial enterprise and work contracts, and therefore subordination, between spouses?

This form of market intrusion into the household caused a rift in legal doctrine and practice between legal experts not ready to consider this possibility and others who were supportive, although with reservations. The courts were divided in the face of the realities of daily economic life leading to disputes openly raising this question. In the interwar period some courts denied the possibility of labour contracts or legal forms of associated activities between spouses on the basis of marital authority, the married woman's legal minority, or the immutability of marriage contracts. Other courts adopted compromise positions. Certain interwar rulings accepted the idea of granting management mandates to spouses, for example, while not subjecting them to the same rules as other proxies, with the argument that trust, solidarity, and the moral foundations of the marriage contract had to be preserved. ${ }^{29}$ 
This type of interpretation was linked once again to gender issues that created a hierarchy within families. Even if the woman was no longer legally a minor, until I965 the husband remained the head of the family, to be entrusted with managing their joint earnings. Progressive lawyers nonetheless called on the legislator to "not stop halfway as it had done in the law of I 8 February 1938 which abolished marital authority, and that it complete the process of the legal liberation of married women". ${ }^{\circ}$ Until well after World War II, however, illustrious legal experts such as Raymond-François Le Bris expressed much more nuanced arguments and insisted that the available legal concepts were insufficient to describe this situation. ${ }^{3 \mathrm{I}}$

In spite of all these nuanced positions, reformers began to prevail in the late i960s. This resulted from a radical change in the political context for female labour issues in particular. The creation of the Committee on Women's Work in 1965, in which Marguerite Thibert participated at the end of an increasingly global career within the ILO, was an important contribution to raising the Labour Ministry's expertise and awareness in relation to female labour. ${ }^{32}$ In the same context, the Women's Secretariat, to which Françoise Giroud was appointed, led by the centre-right president Giscard d'Estaing upon his election, generated the first major survey of assisting spouses: the Claude Report, published in $1976 .{ }^{33}$ At the same time, an ad hoc commission was created in 1977 within the Committee on Women's Work. ${ }^{34}$ Although the sociologist Anne Revillard stressed the committee's autonomy from the Giroud secretariat, the sequence is in itself telling, institutional impetus aside. This period also saw professional associations (chambres des métiers) initiate consultations on recognizing the role of spouses, thereby creating powerful pressure for union organizations seeking to control the election of professional association representatives. This double impetus culminated in a boost to the process, with the election of socialist president François Mitterrand in I $98 \mathrm{I} .{ }^{35}$ His commitment to women's rights during the electoral campaign accelerated an existing trend. The 1982 law can be considered part of a series. A cluster of norms specifically focusing on collaborating spouses was adopted in France between 1980 and 1982.

30. Ibid., p. I 30 .

31. Raymond-François Le Bris, La relation de travail entre époux (Paris, 1965).

32. Anne Revillard, "Stating Family Values and Women's Rights: Familialism and Feminism within the French Republic”, French Politics, 5 (2007), pp. 2 10-228; idem, "L'expertise critique, force d'une institution faible? Le Comité du travail féminin et la genèse d'une politique d'égalité professionnelle en France (1965-1983)", Revue française de science politique, 59 (2009), pp. 279-300.

33. Rapport Claudé.

34. Comité du travail féminin, Rapport sur les conjointes de non salariés.

35. Thébaud, "Réseaux réformateurs". 
The first law recognizing the contribution of spouses participating in a family business once again emerged in the agricultural sector. The large number of spouses involved in farm work and the fear that they might abandon these activities turned agriculture into a pioneering sector. Following the Seventh Annual Agricultural Conference with government officials and agricultural organizations, which took place on 7 July i977, two bills were introduced in the National Assembly and the Senate proposing a civil and professional status for farmers' spouses. Pending the general reform of matrimonial regimes, the concept of a collaborating spouse and co-farmer was thus introduced in the "Agricultural Law" of I980 (Rural Code), guaranteeing recognition of the status of co-farmer spouse and her rights in the administration of the farm's assets. ${ }^{36}$

This was a first step toward the law concerning the status of collaborating spouses in industry and trades, which was finally enacted in 1982 . This law explicitly "relates to the spouses of craftsmen and tradesmen working in a family business", and introduced an important new feature in the French normative landscape on family and business. It decreed the legal creation of the status of collaborating spouse, salaried spouse, and associate spouse of a self-employed worker or entrepreneur. ${ }^{37}$ This was an unprecedented status in French law insofar as its hybrid nature both strictly and metaphorically combines professional and familial ties. And the debate that took place before the law was passed showed that the rapporteur, socialist deputy Odile Sicard, and the deputies who participated in the debate were all aiming beyond the sexually neutral formulation to focus on the wives of self-employed businessmen. ${ }^{38}$ A year later the minister for women's rights, Yvette Roudy, introduced another law on women's rights and against discrimination in the workplace. This law defined professional equality in the broadest sense and was a complement to the 1972 law on equal treatment for equal work. ${ }^{39}$

By creating a favourable environment for the recognition of women's work, France became a model of advances on this issue, not so much for their pioneering nature in Europe (as claimed by the stakeholders) but for

36. Karm, L'entreprise conjugale, pp. 9, 4I. The recognition of a civil and professional status was included in the "Social Provisions" part of the Rural Code, articles 789-I to 789-3. Law no. 80-502 of 4 July 1980 for the agricultural sector, text available online at: http://legifrance.gouv.fr/ affichTexte.do?cidTexte=JORFTEXT00000070 202.

37. Some specific norms concerning collaborating spouses were introduced in the "Agricultural Law" approved in 1980. See Karm, L'entreprise conjugale, p. 9. More recently, the law on "social modernization" 2002-73 published on I J January 2002 also granted a status to the collaborating spouses of professionals, who were not included in 1982 law.

38. JORF, Débats parlementaires, Assemblée nationale, Compte rendu intégral, rère séance du jeudi 8 avril i982, pp. 997-1003.

39. Annie Junter, "L'égalité professionnelle entre les femmes et les hommes: une exigence politique au cœur du droit du travail”, Travail, genre et sociétés, I2 (2004), pp. 191-202. 
their compromise nature. In its 1982 formulation, the law on the status of collaborating spouses revealed the tensions that explain why it was but one step in a long process that began in the nineteenth century and culminated in 2005 . In this specific sense the law is also part and parcel of the parallel and equally contradictory development, lagging behind by a few years, of European legislation.

National legislative delays and progress aside, the French law was created within a larger global context of international social and institutional mobilization that began to gather strength in the I970s. In the context of European integration, these debates focused on employment and productive work for women, beginning with the EEC treaty of 1957 but really enforced with the 1976 directive implementing the principle of equal treatment of men and women at work. This context fostered the creation of a new field that "state feminist sociologists" describe as a relational and institutional "epistemic community" at the crossroads between expertise on labour and expertise on the status of women and equality issues. The debate and subsequent political action were guided by protective and egalitarian principles, and favoured introducing into the family the contractual dimension usually applied to interpersonal relationships in the market economy. ${ }^{4}$

While the international context is not the focus of this study, nor is it just a backdrop. The French protagonists themselves created a link to Europe by claiming their positions were prescient. It was clear in the mind of the rapporteur Sicard that this was an avant-garde law. When the law was presented to the Assembly, André Delelis, the socialist minister of commerce and craft industry, did not hesitate to state in his concluding remarks that: "Passing this bill will grant Frenchwomen and Frenchmen one of the best laws in the European Community on this issue". ${ }^{\mathrm{I}}$ These references to the European level were more than attempts to claim that France was an exception during the heroic days of legislative activity in the first "Mitterrand years"; ${ }^{2}$ rather, they point to a history of crossed

40. Helga Maria Hernes, Welfare State and Woman Power: Essays in State Feminism (Oslo, 1987). On French state feminism see Martine Lévy, Le féminisme d'Etat en France 1965-1985: vingt ans de prise en charge institutionnelle de l'égalité professionnelle entre hommes et femmes (Paris, I988); Revillard, "Stating Family Values"; idem, "L'expertise critique".

4I. JORF, Débats parlementaires, Assemblée nationale, Compte rendu intégral, rère séance du jeudi 8 avril I982, p. IоI 2. André Delelis, mayor of Lens, was the Pas-de-Calais socialist deputy from 1968 to I98 I before becoming Minister of Commerce in the two Mauroy governments from I98I to 1983 , and Pas-de-Calais senator from 1983 to 1992.

42. "'Les femmes sont une force', entretien avec Yvette Roudy, propos recueillis par Delphine Gardey et Jacqueline Laufer", Travail, Genre, Société, 7 (2002), pp. 7-38. I would like to thank Françoise Thébaud warmly for having directed my attention to the European activities of Yvette Roudy. See Françoise Thébaud, "Un féminisme d'Etat est-il possible en France? L'exemple du Ministère des Droits de la femme, I98I-1986”, in Ian Coller, Helen Davies, and 
paths, with much toing and froing between European incentives and French participation in the work of supranational bodies.

Some of the French actors mentioned participated in the activities of transnational networks of experts on these issues. Before becoming François Mitterrand's minister for women's rights from I98 I to I986, Yvette Roudy had served in the European Parliament from 1978 to I98I. With the backing of Simone Veil, elected President of the European Parliament, Roudy became president of a commission on women's rights: "I travelled a lot through Europe and was able to compare the histories and statuses of women".43

During the I970s several countries implemented European measures, and especially those outlined in the 1957 Treaty establishing the EEC that called for "equal treatment" between men and women for work "of equal value". ${ }^{44}$ In The United Kingdom the Sex Discrimination Act of 1975 prohibited any discrimination in employment; furthermore, in Quinnen $v$ Hovells (1984) the courts established that self-employment fell within the scope of the Sex Discrimination Act.

Italy went furthest in recognizing unpaid work with a series of family law reforms in $1975 .{ }^{45}$ These reforms went beyond equal treatment and addressed the situation of family businesses by calling for the elimination of any presumption of cost-free work from either the spouse or other family workers. According to the jurist Stefania Scarponi: "It is a specific regulation at the intersection of family law and labour law, and therefore may be considered a true statute on work in a family business." ${ }^{6} 6$ In contrast, other countries, such as Spain, continued to lack any legal status for collaborating spouses throughout the twentieth century. ${ }^{47}$ Not surprisingly, in France the Italian case was frequently mentioned as an exception in Europe until the French reforms of 1982 . Interaction at the

Julie Kalman (eds), French History and Civilization: Papers from the George Rudé Seminar, vol. I (Melbourne, 2005), pp. 236-246.

43. "'Les femmes sont une force", p. 2 I.

44. Treaty of 25 March 1957, art. I I9 (now I4I), "I. Each Member State shall ensure that the principle of equal pay for male and female workers for equal work or work of equal value is applied. 2. For the purpose of this Article, 'pay' means the ordinary basic or minimum wage or salary and any other consideration, whether in cash or in kind, which the worker receives directly or indirectly, in respect of his employment, from his employer."

45. Law I I I of I9 May i975 reforming the rights of the family and modifying the Civil Code (art. 230 bis). See Karm, L'entreprise conjugale, p. 8.

46. Stefania Scarponi, "Le statut du conjoint dans l'entreprise familiale en droit italien", Annales de l'université des sciences sociales de Toulouse, 4I (I993), pp. 79-86, 80. Art. 230 bis was included in the Civil Code in order to give judicial protection to family workers: until then they were supposed to work free of charge; Scarponi, "Le statut du conjoint", p. 80.

47. Javier Hualde Sanchez, "L'application de la Directive en Espagne", Annales de l'université des sciences sociales de Toulouse, 4I (1993), pp. 47-54. 
European level continued after this year. Of significance from this perspective is the subsequent enactment of a 1986 European directive. ${ }^{48}$ This directive was probably linked to the passage of the French law, as its preamble cites proposals and resolutions dated after $1982 .{ }^{49}$ The directive was based on an egalitarian principle, advocating equal treatment for men and women autonomously engaged in self-employed activities or contributing to these activities (art. I), including agriculture and liberal professions. Significantly, the first assessments made at the beginning of the 1990 s on the implementation of this directive were quite pessimistic. ${ }^{50}$

The legal recognition of unpaid women's work faced several forms of resistance. Resistance in France in I982, and later in the EU on numerous occasions, slowed the adoption of highly innovative ideas and led to soft norms aiming to compensate for legal and social shortfalls in the recognition of a spouse's unpaid work. This resistance stemmed from tensions surrounding the opposition, once again, between the market model, which is based on market exchange relations determined by contracts among freely consenting individuals, and the family model, which is based on mutual aid and solidarity.

A book commenting on the rights of craftsmen's spouses in the wake of the 1982 law surveyed the discrepancies between marriage, business, and labour law, and concluded by valorizing the status of the undeclared assisting spouse: ${ }^{\text {I }}$

The assistant's activity is neither motivated by the search for an official status nor maintained for the sake of preserving it. Rather, the assistance is a voluntary, spontaneous, and disinterested contribution of the type that marriage law prescribes spouses to provide to each other where needed, by stating that they owe each other mutual $[\ldots]$ assistance. (Code civil, Art. 2 I 2$)^{52}$

This kind of statement was expressed not only in legal debates but also by the courts. Despite legislation in principle favourable to recognizing

48. Institut de droit comparé des pays latins de l'Université de Toulouse, L'entreprise familiale en Europe: colloque international, $25-26$ mars 1993 (Toulouse, 1994). This conference provided a survey of the application of the 1986 directive in Europe.

49. After the 1957 Treaty establishing the EEC (articles I00 and 235 and not I I9), the following are cited: the Commission's proposal, the Assembly's opinion, the Economic and Social Committee's opinion (JORF, no. C I I 3,27 April I984, p. 4; JORF, no. Ci 72 , 2 July I984, p. 80; $J O R F$, no. $\mathrm{C}_{343}, 24$ December I984, p. I; JORF, no. Ci 86,2 I July I982, p. 3), and the Council's resolution of $\mathrm{I} 2$ July $\mathrm{I} 982$ on the promotion of equal opportunities for men and women and its approval of the Community's new action programme on promoting equal opportunities for women (1982-1985).

50. Nathalie Wuiamé, "Présentation de la directive du conseil du i décembre I986", in Institut de droit comparé des pays latins de l'Université de Toulouse, L'entreprise familiale en Europe,

pp. 29-37.

5. Martin, Le conjoint de l'artisan, p. 2.

52. Ibid., pp. 90-91. 
the statuses and rights of spouses, even Italy - as we have seen, one the most advanced countries in terms of family business regulation - saw a raft of adverse court rulings on unpaid work in the r980s, and such adverse rulings continue to appear to this day. ${ }^{53}$ These rulings were made citing the feeling of affection and mutual aid that are specific to married couples (this affectionis vel benevolentiae causa may include the case of a loan that was unpaid in the name of solidarity between partners). As demonstrated by the jurist Maria Rosaria Marella, legislation offering a market definition of roles does not suffice to change dominant representations and practices associated with these roles. ${ }^{54}$ Highly novel laws do not prevent behaviours as well as rulings based on older ideas, or in any event non-economic ones, of relationships between spouses defending their moral character. These conceptions consider the contractual dimension as disruptive to familial cohesion. Yet historians, sociologists, and even jurists have shown that contractual relations are not necessarily bereft of feelings. 55

\section{Achievements and limitations of the 1982 law}

Understanding how these opposing models are linked in practical terms requires returning to the enactment of the 1982 law, our main normative and chronological point of reference. From this perspective the achievements of the 1982 law are undeniable: it was legitimately considered a novel law that defined the occupational status of a spouse's labour. From the outset, in its first article, the law recognized the occupational aspect of the spouse's activity and made a basic distinction between intangible and material mutual aid between spouses, and intangible and material contributions that are also professional. On this point the parliamentary committee tasked with preparing a report on the proposed law overcame the legal opposition between spousal help, and work and partnership contracts. This aspect is especially important because even in the I980s spouses were no more aware than before of the specific nature of their contribution to the smooth running of the company. ${ }^{56}$ As labour

53. Maria Rosaria Marella, "The Family Economy versus the Labour Market (or Housework as a Legal Issue)", in Joanne Conaghan and Kerry Rittich (eds), Labour Law, Work, and Family: Critical and Comparative Perspectives (Oxford, 2005), pp. I57-175; Maria-Rosaria Marella, "Critical Family Law", American University Journal of Gender, Social Policy \& The Law, 19 (20II), pp. 72I-754. See Laure Ortiz, “À propos du genre: une question de droit", Droit et société, 80 (2012), pp. $225-235$.

54. Marella, "The Family Economy versus the Labour Market", p. I6r.

55. Ibid., pp. 161-163. Some suggestions on this topic from a historical point of view are discussed in Manuela Martini, "Rapports patrimoniaux et crédit dans les ménages nobles. Dot et apanage des femmes à Bologne au XIXe siècle”, Clio, 7 (1998), pp. I55-176.

56. Zarca, "Indépendance professionnelle", p. 9 I. 
sociologists have shown, the share of family workers who declare themselves as such rather than "without an occupation" varies depending on the survey and question sequencing, but it remains consistently small. In the INSEE's I982 "Family" survey, I6.2 per cent of women polled reported working as assistants to a family member, whereas in the following year's "Employment" survey 27.5 per cent reported that they were assistants. Of course, the awareness of being engaged in an occupational activity was higher if the spouses had degrees, especially for the spouses of liberal professionals ( 90 per cent), but it was only 60 per cent for the wives of food merchants and artisans, and fell to 53 per cent for the wives of construction-industry entrepreneurs. ${ }^{57}$

Yet a declared occupational activity yields three statuses that share the particularity of having adjectives - associate, employed, and collaborating - qualify the spouse, which is the principal term in this nominal group. This implies the recognition of formal equality between spouses in the family: France only officially established equality within the family with the law of I 3 July 1965. Despite abolishing the institution of husband's authorization in 1938, French law continued to qualify the husband as head of the family. ${ }^{58}$ This asymmetry was invoked to forbid work contracts implying a subordinate relationship between a husband worker and wife employer, even if in real life they frequently existed, of course (see for example the video testimony of a I950s baker couple in the INA's archives). 59

For our purposes it is also interesting to note the principal difference between the statuses of employed and associate spouse and that of collaborating spouse. In the first two cases the spouse is remunerated through operating profits or a monetary salary for participating in the company's work, but this is not the case for the collaborating spouse. The latter, called a collaborator and not an assistant to highlight the non-ancillary nature of the work, is, as such, unpaid and until 1989 was furthermore prohibited from working outside the company. This status nonetheless grants certain rights, mostly in terms of managerial autonomy and social security. The collaborating-spouse status assumes an implicit mandate from the head of the company for administrative acts.

57. Ibid., pp. 91-92; see Battagliola, Histoire du travail; Sylvie Schweitzer, Les femmes ont toujours travaillé. Une histoire du travail des femmes aux XIXe et XXe siècles (Paris, 2002). 58. Martin, Le conjoint; Karm, L'entreprise conjugale.

59. Archives of the Institut National de l'Audiovisuel [INA], television report, La Première femme maître-boulanger [The first female master baker], Journal Télé, I 9.15 hrs, 20 November 1960, duration 2 mins 4 secs. Interview with Monsieur Götz, baker: "C'est ma femme le patron" [It's my wife who's the boss], "Elle doit m'obéir le soir" [She has to obey me in the evening], http://www.ina.fr/economie-et-societe/education-et-enseignement/video/CAF95053754/ premiere-femme-maitre-boulanger.fr.html. 
Moreover, the declared collaborating spouse receives certain social security benefits in kind (medical expenses, medicine, testing) but no daily allowance in the event of illness, nor any income replacement during maternity leave (one of this law's elements that is most unanimously opposed by the spouses of the self-employed, whose exclusion dates back to the origin of these rights in 1913). ${ }^{60}$ Most importantly, collaborating spouses obtain their own rights to retirement if they are covered by their trade's old-age pension scheme, that is, by the same fund to which the head of the company is affiliated.

But all of this hinges on a voluntary, non-compulsory filing of a declaration to the Trade Register and Trade Directory. Until i985 the company head's consent was also required (in order to protect the business but, as most of the heads were male, it is also clearly reminiscent of the marital power transposed to the business head here). In the event that the spouse was not declared, he or she would remain without a status, with but a few additional rights in terms of social security.

\section{Institutions: social and tax laws, and factual resistance}

Figures from various studies conducted since 1982 on the law's reception admittedly trailed the most pessimistic forecasts; in 1986, 20,000 out of around 300,000 collaborating spouses in the crafts, or only 6.6 per cent, were declared. For employed spouses the figures were I.I per cent in I 983 and 1.6 per cent in I989, and for associates I.3 per cent in 1983 and I.4 per cent in $1989 .{ }^{61}$ An overwhelming majority of spouses therefore chose no status. Yet, beginning in 1985 for craftsmen and 1986 for merchants, self-declaration was possible. Granted, the business head could contest the declaration in the event of disagreement, but the change was still significant. While the husband was free to oppose, he had to do so actively, rather than express opposition through his passivity and lack of motivation to declare his spouse to the professional association.

Why this resistance in the practical realities of family business management? The reticence of craftsmen and their spouses can undoubtedly be explained on the one hand by sociological and cultural factors and, on the other, as they themselves claim, by serious economic constraints. A third compounding factor is the institutional context, which was shaped by gendered social and cultural constructs. This last explanation

60. See Paul Pic, Traité élémentaire de législation industrielle. Les lois ouvrières (Paris, 1903), pp. $453-463$.

6I. Zarca, "Indépendance professionnelle", p. IоI. See also, idem, L'artisanat français. Du métier traditionnel au groupe social (Paris, 1986); Steven M. Zdatny, The Politics of Survival: Artisans in Twentieth-Century France (Oxford, 1990), translated as Les artisans en France an XXe siècle (Paris, 1999). 
is indeed inherent in the way social law and tax law treated family workshops throughout the twentieth century.

The logic of continuity was expressed in views on the nature of moral and economic relations between spouses, but it was also shaped by the definition of family workshops in legislation as exempt from some tax and social constraints. The labour and social regulation that began in I84 I and continued up to I 874 , and the I 892 laws on children and women's work exempted these workshops from the requirements that industrial plants had to meet, particularly regarding night work for women and minors, and maternity leave. ${ }^{62}$

The 1892 law protecting children and women in the workplace formally defined family workshops. In addition to the exemption from social legislation, these workshops were granted tax exemptions. The special provisions granted to craftsmen in 1917 , and again in 1923 , confirmed the state's classification of this occupational grouping, whose union representation had been founded a year earlier, and displayed a close connection between the family character of family craft business and these provisions. ${ }^{63}$ Craftsmen were taxed based on their emoluments and salaries and no longer according to their industrial and commercial profits. Family workshops run by craftsmen and which used unpaid family workers (and apprentices, who, until I97I, did not have the status of employees) were also exempt from a local tax (the patente) payable by every economic trade.

Meanwhile, couples working in the same small enterprise with a salaried collaborating spouse and not married on the basis of separate ownership of property were prohibited from deducting a spouse's salary from industrial and commercial profits. Fearing fraud and the deduction of false salaries (not really being paid to spouses), the state - not just "moral" and social norms - forced spouses to operate as a single productive unit. A small rebate of only io per cent was granted in a law enacted in $1938 .{ }^{64}$ As emphasized by feminist economists, tax policy

62. As was the case for all nineteenth-century child labour laws, especially those of $\mathrm{I} 84 \mathrm{I}$ and I 874 , and even the law of 2 November I 892 on the labour of children, minor girls, and women in industrial factories, family workshops were exempt from having to implement the law's protective measures. This led to a precise definition of family workshops: workshops where the work is done "by hand" under the supervision of the father, mother, or a tutor. However, hazardous industries were not exempt even if the work was not mechanized. See Pic, Traité élémentaire de législation industrielle, pp. 453-463, and for a more general commentary see Battagliola, Histoire du travail, pp. 45-46.

63. Nicolas Delalande, Les batailles de l'impôt. Consentement et résistances de 1789 à nos jours (Paris, 20II), p. 3 I 2.

64. Karm, L'entreprise conjugale, pp. 34-35, 39-4I. The Conseil d'État admitted the possibility of the woman's wage being deducted (for the first time in 1919) only for spouses married 
affects economic activity and the gendered status of the economic actors who contribute to it. ${ }^{65}$

Thus, the tax exemption defines a specific form of family business: the family workshop as a collective entity, but one that in this particular vision involves the fusion of its elements and merging with the (male) head of the family. ${ }^{66}$ On the other hand, small but more exogamic family businesses were considered "normal" taxed businesses. ${ }^{67}$ In both cases, the result was the persistently unpaid and unrecognized status of "assisting" spouses.

Besides taxes, there are two more explanations for the lack of recognition of their work. The first was the poor political reception at the national and international levels to proposals from certain groups of feminist reformers. ${ }^{68}$ The second was the particular conception of how family craft

without community of property, because until 1965 under the community of property regime the woman's wage was supposed to be managed by her husband.

65. See, for example, Lisa Philipps, "Tax Law and Social Reproduction: The Gender of Fiscal Policy in an Age of Privatization", in Brenda Cossman and Judy Fudge (eds), Privatization, Law and the Challenge to Feminism (Toronto, 2002), pp. 4I-85; idem, "Silent Partners: The Role of Unpaid Market Labor in Families”, Feminist Economics, I4:2 (2008), pp. 37-57.

66. This concept is also fully compatible with the criteria established by statisticians in the midnineteenth century to identify occupations where all family members, including servants and siblings, live off the profession of the family head. Between I 856 and I 896 statisticians tried to determine "the number of individuals who directly and indirectly support each profession in France" (Statistique générale de la France, Recensement, i 856, p. xxxiii, quoted in Battagliola, Histoire $d u$ travail, p. 19). Later, other concepts, such as individual assignment to an occupational class, led to an underestimation of family workers. Since I 896 census statistics have been based on a definition of labour as involving the commercial exchange of goods and services. This restriction of labour to market labour led to the "disintegration" of domestic work unity and to a separate classification of women and children (thus considered inactive population) on the one hand and of servants (active population) on the other. See Christian Topalov, "Une révolution dans les représentations du travail. L'émergence de la catégorie statistique de 'population active' au XIXe siècle en France, en Grande-Bretagne et aux Etats-Unis”, Revue française de sociologie, 40 (1999), pp. 445-473, translated as "A Revolution in Representations of Work: The Emergence over the I 9 th Century of the Statistical Category 'Occupied Population' in France, Great Britain, and the United States”, Revue française de sociologie, 42 [Supplement] (200I), pp. 79-106. In I 896 the inactive population category included "individuals living off the income of others without being paid in the ordinary sense of the word", that is, not only women who "exclusively attended to their household", but also all the family workers who contributed unpaid productive work to the family business (Recensement, I896, IV, p. xii), Battagliola, Histoire du travail, p. 22.

67. One of the most important points of the parliamentary debate that took place before the 1982 law passed was a tax deduction from wages. When the law was introduced to the Assembly in 1982, the minister of commerce and craft industry, André Delelis, stated that "the only roadblock to any progress on granting an employee status to spouses is that the business cannot, from a tax perspective, afford an additional employee without a tax deduction from wages through the BIC [industrial and commercial benefit]"; JORF, Débats parlementaires, Assemblée nationale, Compte rendu intégral, ı̀̀re séance du jeudi 8 avril I982, p. IoI 2.

68. This is the view of feminist scholars and sociologists such as Bernard Zarca. 
businesses function and operate that was shared by a significant number of the reform movement's leaders. With regard to this conception, I would like to analyse the interpretations at the crossroads of business and household rationales that were created and used by some of the activists, themselves assisting spouses, and that led to the first and highly symbolic I982 law. These interpretations aimed to recognize the occupational contribution of spouses while structuring its form in line with the principles of a traditional gender-oriented division of roles within the workshop. With the benefit of hindsight, one can see that these interpretations nonetheless contributed to modifying the internal hierarchies of the family workshop. Once historicized, this process can be understood as a way of gaining acceptance for change in this kind of conservative milieu.

For sociologists who studied craftsmen in the I980s and 1990, and particularly Bernard Zarca, who, without a doubt, analysed the most deeply the challenges to relationships between spouses in family businesses starting at the end of the r 980 s, the optional nature of the declaration made a failure of what had been considered a victory by the law's proponents. ${ }^{69}$ Thus, the law was not a turning point in the relationships of spouses in family businesses, but rather, more modestly, a very liberal and non-binding law that left the door open to the persistence of informal collaboration.

Was it merely a symbolic victory? Having provided some insights into its contents and limitations in affecting craft household practices we will now try to show how it changed power relations and goals in union organizations and the perception of unpaid work of assisting spouses, to the point where a much more binding law became possible in 2005 .

\section{LOBBIES, PROFESSIONAL UNIONS, AND THE 1982 LAW}

Given the heavy patriarchal yoke and the entrenched model of craft business managed by a head acting as a good family man, a paterfamilias of a family business, in what way was the 1982 law a victory for its supporters, at the time and forty years later? Turning to one of the innovators in the movement to recognize the status of women, Marie Rozet, now an octogenarian, does not waver forty years later when asked about the date of promulgation and name of the law of ro July i 982. Rozet, still active in the FENERA National Federation of Craft Retiree Associations, is a key witness to the various and contradictory visions of collaboration between spouses in business (Figure I). As a collaborating

69. For legal experts the limitations are linked to the creation of a status without inscribing it in a coherent body of law (Italian law is mentioned as an example of consistent treatment; German is as well, but for the opposite reason since it recognizes wages). See Karm, L'entreprise conjugale, pp. 8-I 2 . 


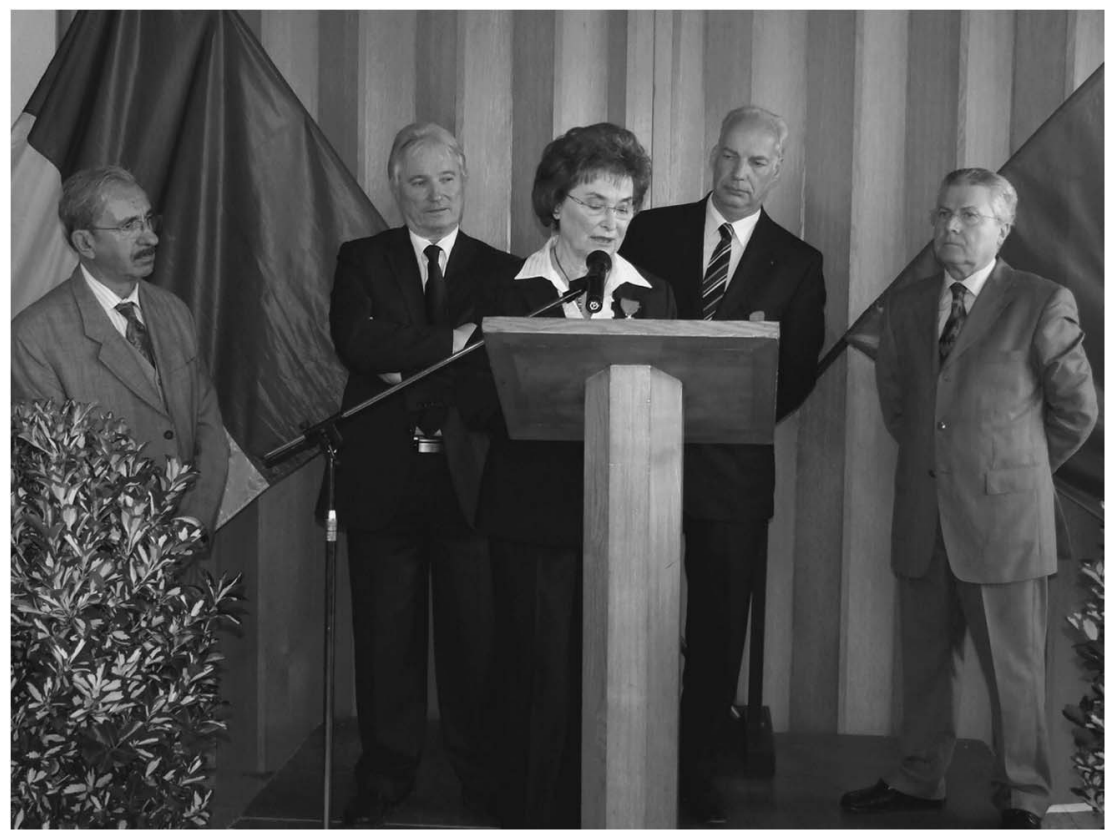

Figure I. Besançon, 6 May 20I I. Marie Rozet, former President of the Commission Nationale Femmes d'Artisan and of the FENARA, the National Federation of Retired Artisans, receives the title of "chevalier de la Légion d'honneur" for her "sixty years of professional and community activity". At the back, from the left, Claude Rozet, Marie's husband, Bernard Barthod, President of the Trade Chamber of the Doubs, Alain Griset, President of the Permanent Assembly of Trade Chambers (AMPCMA), and Serge Thivenin, President of the FENARA. ${ }^{70}$

Chambre de métiers et de l'artisanat du Doubs, 20II. Used with permission.

spouse of a construction painter and decorator in Franche-Comté, she served as a leader of local associations within the Construction Craft and Small Business Confederation (CAPEB) and as founder of the National Commission for Craftsmen's Wives, which she presided over for several years. Created in 1979 within the CAPEB as a gender-defined institution, it was integrated into the CAPEB's representative bodies and later became the most important institution for spouses in the Crafts Union (UPA).

70. An announcement of this decoration was made in the JORF, no. I, I January 20II, p. 9, Décret du 3I décembre 2010 portant promotion et nomination, Légion d'honneur, Premier ministre, "Mme Rozet, née Fillod (Marie, Clémentine, Marthe), présidente de la Fédération nationale des associations de retraités de l'artisanat; 60 ans d'activités professionnelles et associatives". 
The CAPEB was one of the first trade-union associations to respond, beginning in the mid-I970s, to requests from the top and from the bottom. Requests from the former, in particular, increased after the creation of the Women's Secretariat by Françoise Giroud, while the latter resulted from the spontaneous mobilization of spouses who met among themselves on the margins of national meetings for the departmental federations of construction trade associations. This early embrace in one of the most male-dominated sectors of small business might be surprising. Union politics were likely behind the support of CAPEB leaders for this initiative: to control the spouses' conduits and then the seats that would be allocated to them, beginning in 1980 , in the professional associations (chambres des métiers).

I would argue that this mobilization was based on a sector-specific gender dimension. This statement might seem counterintuitive, because it is well known that the building and public works sector is one where the share of women's paid work is still very small, barely totalling 5 per cent in 1980 and no more than 10 per cent today in all categories combined (3 per cent of workers in 2010). ${ }^{71}$

Moreover, the sector's male dominance plays an important role in self-perceptions of contributions to the family business. ${ }^{72}$ Indeed, collaborating spouses in the construction sector display the least consciousness of their occupational contribution: only half of these women clearly recognized their contribution..$^{73}$ Because they often perform their functions at home or at the headquarters of the business, far from the entirely male worksites, the tasks assigned to the spouses are stripped of some of their symbolic significance. The valorization of production work and technical mastery is greater than that of women's service contributions (accounting, relationships with clients and suppliers). However, a considerable number of women are involved in these activities.

Recalling the statistics estimating the number of spouses assisting business owners in the construction sector, we know that of the $2,346,500$ companies employing fewer than 20 people, 950,000 are craft companies (that is, members of professional associations or chambres des métiers), of which one-third are construction companies, totalling 356,000 in 2004 . Thus, of 300,000 craftsmen's spouses affected by the 2005 Dutreuil Law, around 100,000 work in the construction trade.

The significance of this female workforce became inescapable in the I970s, a real turning point not only because of the state's intervention in recognizing spouses, but also because of major changes in the economic

7I. CAPEB - Lettre trimestrielle d'informations de l'Artisanat du Bâtiment - zème trimestre 2008 .

72. INSEE "Family" survey, I982, quoted by Zarca, "Indépendance professionnelle”, p. 91.

73. As we have seen above (text and n. 57), they were 53 per cent. 
and social context. These changes were partly due to the economic crisis and partly to the transformation of gender relationships that noticeably accelerated beginning in the mid-1970s. ${ }^{74}$

The effects of several crises suddenly attuned a priori unresponsive professional organizations to women who were in difficulty and deprived of any social rights (unemployment, retirement, medical insurance) in the aftermath of family business bankruptcies, which became very numerous from the end of the i 970 . The increasingly flexible work practices also threatened unpaid spouses, as communist deputy Muguette Jacquaint emphasized during the 1982 parliamentary debate. ${ }^{75}$ The crisis constituted a double jeopardy for women. Without resources or technical skills certified by official diplomas, they ended up more impoverished than their husbands, who could more easily transition to becoming employees.

As the number and rate of divorces began to soar in 1970 , there were more frequent and visible cases of spouses who had worked for decades in a business and found themselves completely destitute after their separation as they were cut off from any social rights linked to the work they had carried out. Indeed, the available divorce statistics broken down by professional group show that craftsmen getting divorced in I 970 had a relatively high average length of marriage: thirteen years (Figure 2). ${ }^{76}$ Their marriages were longer-lasting than those of employees and middle management (eleven years on average), but much shorter than those of large industrialists and farmers (around fifteen years). The family pattern of the business probably played a role in the intermediate position of divorce rates among craftsmen (divorces in 1970 compared with the number of couples married in 1968) when compared with managers and farmers: 4.I per I,000 marriages compared with 9 per I,000 for employees and 9.4 for middle management professionals (2.4 for large industrialists and 0.7 for farmers). Nevertheless, the overall trend was increasing during these years and affected all socioeconomic categories.

In this context a movement formed and succeeded in bringing together several tens of thousands of spouses (about 2 per cent of the total), a sizeable figure given that in France the proportion of union employees at the beginning of the 1980 s was no larger than 7-8 per cent in the SMEs. ${ }^{77}$

74. Jean-Paul Sardon, "L'évolution du divorce en France”, Population, 5 I (1996), pp. 717-749. 75. JORF, Débats parlementaires, Assemblée nationale, Compte rendu intégral, rère séance du jeudi 8 avril 1982 , p. 999 .

76. Anne Boigeol and Jacques Commaille, "Divorce, milieu social et situation de la femme", Economie et statistique, 53 (1974), pp. 3-21, 9.

77. The 1976 Claudé Report voiced the first claims of women concerned about their retirement or maternity allowance and replacement benefits, but also the problems related to their role as managers and wives faced with the danger of confusion between family and business assets. After this report the CIDUNATI union (with the majority in the Paris professional association) took the initiative to organize a joint meeting in Paris that gathered women meeting in local 


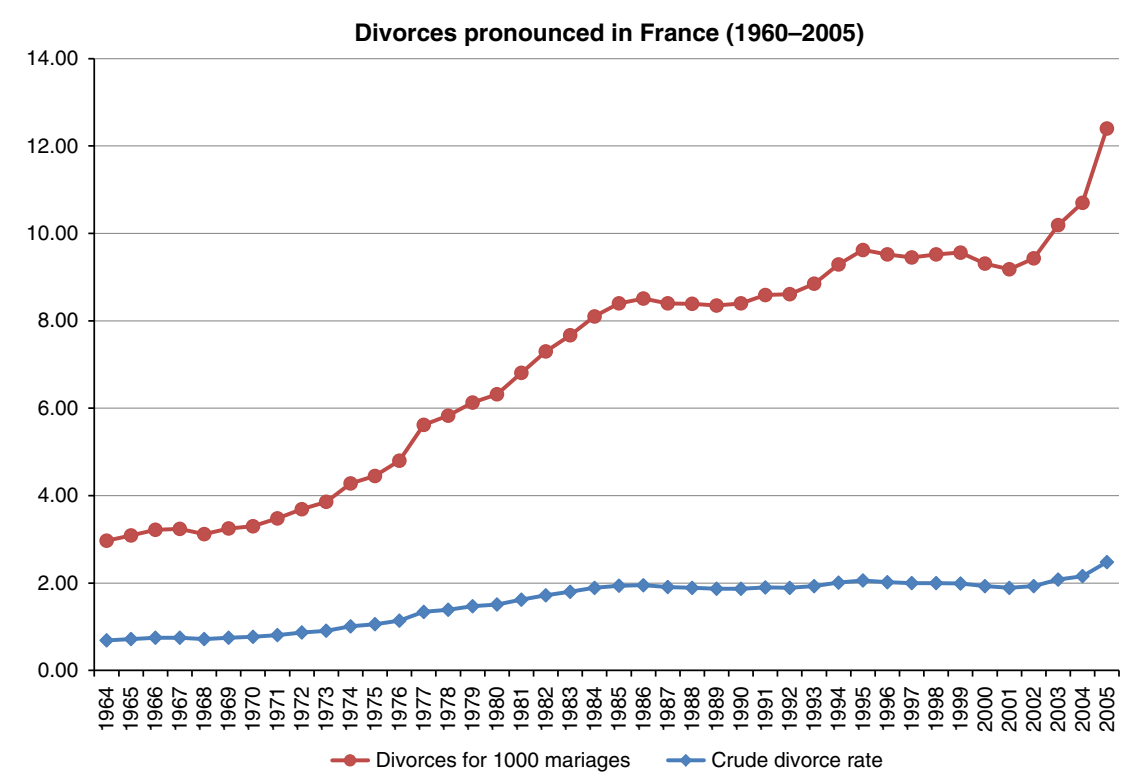

Figure 2. Divorces pronounced in France, 1960-2005.

INSEE, Résultats. Société, 66, June 2007.

Pressured from both the top and the bottom, the CAPEB, followed by the bakers' federation, one of pillars of the craft and food confederation and a sector where spousal labour plays a major and essential role, organized ways of representing spouses, including at the level of national boards of directors. This was quite a significant achievement.

\section{Acting for collaborating spouses and dealing with conflicting models}

Everything went well. You have to get to know the men you're working with. I was able to earn their respect while knowing when to have a sense of humour. I had the same place they did around the table. The advice I would give to the future president is to be feminine without being a feminist. ${ }^{7^{8}}$

civil society associations. This meeting in Paris created the ADEAC, an association of the wives of craftsmen and tradesmen, which lost most of its members after the law of 1982. See Zarca, L'artisanat français; idem, "Indépendance professionnelles"; Zdatny, The Politics of Survival; and Michel Cézard and Jean-Louis Dayan, "Les relations professionnelles en mutation", Données sociales, (1999); English translation available at http://www.insee.fr/EN/ffc/docs_ffc/ ds9927.html.

78. Batiactu, journal available online, interview conducted in $20 \mathrm{I}$, "Etre féminine sans être féministe!", Roselyne Lecoultre, Administrateur et Présidente de la Commission nationale des femmes d'artisans de la Capeb, http://www.batiactu.com/edito/les-femmes-dans-le-btpquelle-place-quel-role-qu-p4-25589.php; last accessed 20 March 2012. 
At the end of her term as president of the National Commission of Craft Women (CNFA) in 2010, Roselyne Lecoultre passed on the torch by recalling the basis for the very existence of her position. Her speech revealed explicitly the double dimension of this public role. On the one hand she had a position of responsibility sitting at the executive table and on the other she represented a feminine approach offering other ways of acting in order to be heard. Far from seeing a possible contradiction between these two attitudes and roles, she implicitly proposed to turn female diversity into a policy tool that was detached from any connection to the feminist movement. ${ }^{79}$

When her senior, Marie Rozet, speaks of the heroic times of the first battles, she insists on the fact that the women who met at the margins of the CAPEB's national conferences were not feminists. The first time she went to Paris as a women's representative on the national board of directors, she was accompanied by her husband since "she was not accustomed to going up to Paris (from her native town of Besançon, Franche-Comté) alone”. ${ }^{80}$ When publishing a book on the laws and norms concerning the status of collaborating spouses in the I990s, she included Baroness Bertha von Suttner's famous quotation on the first page: "After the verb to love, to help is the most beautiful verb in the world." ${ }^{8}$ The language they use is identical. All the attributes of a feminine attitude toward the role of a spouse are included in this quotation. But this feminine understatement, without any doubt absolutely genuine, may also hide an undeclared political strategy.

This group of women involved in the defence of spousal rights within trade unions was premised on avoiding any hint of feminism. Until very recently, representatives of the Women's Commission were the only women who participated in the meeting of the national board. In order to be accepted on the entirely male national boards of the CAPEB and of the Union of Artisans (UPA) it was in their great interest to present themselves as the helping angels of the workshop (as well as of the home, des anges $d u$ foyer).

The women involved in the direction of the Women's Commission also had to place the institution ahead of themselves: none of the former

79. On the feminist movement in France and Europe see Dictionnaire critique du féminisme, coordinated by Helena Hirata, Françoise Laborie, Hélène Le Doaré, and Danièle Senotier (Paris, 2000); Karen Offen, European Feminisms, I700-1950: A Political History (Stanford, CA, 2000); and Eliane Gubin et al. (eds), Le Siècle des féminismes (Paris, 2004).

8०. She adds: "But in the meantime things have changed, I assure you"; interview with Marie Rozet, 4 October 20I I and 4 April 2013.

81. Marie Rozet, Le couple dans l'artisanat et le commerce: 16 fiches sur les droits du conjoint (Paris, 1996). The book was dedicated to Michelle Cristin, regional deputy for women's rights "for the activities she carried on in Franche-Comté", and "to the women who enchanted my union life". For her active pacifism Suttner was the first woman to earn the Nobel Peace Prize, in 1905 . 
presidents could be "honoured" and exist autonomously despite their regular and indispensable presence in these bodies. None of the publications that reconstruct the history of the CNFA's achievements mention the names of those who made its history: Marie Rozet, President from I 979 to 1982, Dany Bourdeau from I 982 to 1999, and Roselyne Lecoultre from 1999 to 2010 , do not appear anywhere in the annals of the CAPEB.

Moreover, it would have been difficult to imagine a complete transformation of views on the role of women in an environment that sociologists who did fieldwork in the I970s and 1980s described as reliably conservative with regard to gender relations, although not necessarily always politically aligned to the right or extreme right. ${ }^{82}$ Concrete examples of these perspectives abound in the pages of the professional publications of the day. The November 1975 "Women Readers' Letters", a section that was regularly featured in the CAPEB's Craft Building journal, included, for example, an article on "the increase in allowances for stay-at-home mothers", "a list of school holidays 1975-1976", a note from the association for the professional training of adults, as well as a piece on the creation of a "women's focus group by M. Galley, Minister for Infrastructure”, "to obtain feedback from women on daily life", where questions about urbanism, housing, and their environments seemed secondary. ${ }^{83}$

Yet in 1974 a previous issue had reported on a general assembly of craftsmen's wives that had taken place in Dordogne alongside the assembly of the union committee for local craftsmen and small businesses in the construction sector. ${ }^{84}$ The assembly brought together close to I०० people to discuss, according to the minutes, management problems concerning treasury issues and the drawing up of estimates in a context of rapid price increases (therefore, they did not only discuss school holidays). The meeting's success generated the idea of creating several working groups that could regularly meet. ${ }^{85}$ The aims of this spontaneous movement - the training and recognition of collaborating spouses converged with a broader international and national push from European and French institutions in charge of women's labour rights.

In March 1975, International Women's Year, at the time of the CAPEB's general congress an entire page of the CAPEB's journal was

82. Nonna Mayer, La boutique contre la gauche (Paris, 1986); Philippe Casella and Pierre Tripier, Qualification sociale et professionnelle dans l'artisanat du bâtiment (Paris, 1988). For a historical point of view on this issue see Zdatny, The Politics of Survival; Philip Nord, Paris Shopkeepers and the Politics of Resentment (Princeton, NJ, 1986).

83. Le bâtiment artisanal, 1975, 226, v. 23, p. II.

84. Le bâtiment artisanal, I974, I I2, v. 22, p. 27.

85. Le bâtiment artisanal, 1975, I19, v. 23, “Assemblée générale Périgueux”, p. 21. 
dedicated to spouses, ${ }^{86}$ who evidently did not just discuss management problems this time: "Gathered in Paris for the CAPEB's national conference, the wives of craftsmen requested that their work in the company be recognized. The federal administrative commission tasked president Marcel Lecoeur to meet with a small group of craftsmen's wives who regularly participate in business management" (this was the case for 70 per cent of craft construction business according to the figures published by several sociologists in the 1980s). ${ }^{87}$ Their demands, shared by their spouses, as the article notes, were presented in a very neutral way: "this interview revealed that craftsmen and their wives working in the business would like spouses to be guaranteed the same social security benefits as the salaried boss and benefit from developments in the social protection of employees". 88

This carefully pursued behind-the-scenes approach explains how they were able to achieve some of their claims. Indeed, despite the wives' careful and anti-feminist positioning, out of conviction or for strategic reasons many would have considered this back-door strategy unacceptable. But most business heads were ready to recognize that their spouses' claims were not anathema to theirs. Because the craft organizations at the time were much more akin to trade organizations than employer organizations, ${ }^{89}$ they could openly advance some of the claims of craftsmen's wives, especially those regarding equality of treatment with employees in terms of social protection: retirement, the establishment of a health insurance scheme, and income replacement during maternity leave. While these benefit provisions would make spouses more autonomous, by keeping them as a discretionary, non-binding option, without any obligations, they were made more acceptable to moderates.

Furthermore, very modern and novel approaches to the spouse's professional contribution that focused on status recognition could very

86. To mark International Women's Year in 1975 , the Economic and Social Council, to which Marcel Lecoeur had belonged since 195 I, discussed and approved on is October 1975 a report drawn up by the sociologist Evelyne Sullerot entitled Problems of Work and Employment of Women; Conseil économique et social, Les Problèmes posés par le travail et l'emploi des femmes, Avis adopté par le Conseil Economique et Social au cours de sa séance du Is octobre 1975 (Paris, 1975). I would like to thank Alain Chatriot for his kindness in directing me to this information on the Marcel Lecoeur dossier. For more on this public consultative institution see Alain Chatriot, La démocratie sociale à la française. L'expérience $d u$ Conseil national économique 1924-I940 (Paris, 2002).

87. Zarca, L'artisanat français, pp. 223-232.

88. Le bâtiment artisanal, 1975,23 , v. 220, p. I6.

89. Marc Milet, "Dialoguer pour exister? Le syndicalisme artisanal en quête de légitimité par le dialogue social (archives)", Terrains E Travaux. Revue de sciences sociales, I4 (2008), pp. 68-89; idem, "Parler d'une seule voix. La naissance de l'UPA et la (re)structuration du syndicalisme artisanal au tournant des années 70", Revue française de science politique, 58 (2008), pp. $483-5$ IO. 
well be part of a familial model based on complementary roles in the family business. A company could be hierarchical and involve joint economic goals, but it also could - and since 2005 must - leave room for the recognition of individual professional interests, allowing for a spouse's autonomy in the event of a crisis or breakup.

\section{CONCLUSION}

Indispensable to overcome economic constraints and uncertainty for small family businesses, the unpaid work of a spouse became a sensitive issue in the political and juridical changing arena of the I960s and I970s. The long-term historical perspective adopted here helps to understand the emergence in the interwar period of a contractual model defining economic relationships within the family. This recognition of an economic contribution, giving the right to compensation or, at least, to social security benefits, coexisted during the second half of the twentieth century with a longstanding one, based on mutual obligations between spouses in a family business. The compromise that gave rise in 1982 to a law recognizing the legal status of collaborating spouses in commercial and craft businesses reflected the deep social and legal resistance that account for the slow embrace of the law. We have traced the path that gradually, step by step, led to the dismantling of institutions that involved tight gender constraints and the economic subordination of the wife to her husband - indispensable preconditions for the development of a status. But the nature of matrimonial relations and the duty to provide mutual aid remained controversial. It is significant that the French Court of Cassation has still not ruled on the nature of "the work provided by one spouse for the other", or the validity of a work contract between spouses..$^{\circ \circ}$

Shifting from the legal to the social arena, an analysis of the positions taken by female players in the movement makes it clear that the categorization of spouses in an ancillary role was internalized, especially in some trades. However, it is too drastic a view to reduce the status of these women to that of a dominated person. ${ }^{9 \mathrm{I}}$ For some women it was a positive lifestyle choice that allowed greater freedom in time management, more flexible working relationships, and the pleasure of doing work that involved a certain degree of responsibility. They were often in charge

90. Karm, L'entreprise conjugale, p. 33.

91. Pierre Bourdieu, La domination masculine (Paris, 1998). But several feminist historians are rather sceptical and have a more nuanced opinion on this issue. See, for example, the research on the role of women in silk family workshops by Mathilde Dubesset and Michelle ZancariniFournel, Parcours de femmes. Réalités et représentations. Saint-Etienne, I880-1950 (Lyon, I993), pp. 93-96. 
of accounting and therefore the first to cut back on retirement contributions if the business experienced financial difficulties, even if they would later regret it upon retirement or in the event of a divorce.

Defending the non-compulsory character of the declaration of a collaborating spouse, the rapporteur of the 1982 law, the socialist deputy Odile Sicard, was counting on the status recognition to affect mentalities. ${ }^{92}$ The poor statistics concerning declared collaborating spouses in the last few decades of the twentieth century may lead one to conclude that she was too optimistic. However, though there was a reluctance to implement the law in business practices, the law did legitimate a new space of action and claims for spouses' social rights on the boards of craft and trade unions. Political awareness sufficiently evolved to allow for the 2005 law and the mandatory attribution of a status to a spouse (accompanied by mandatory old-age pension contributions for all collaborating spouses). The uncompensated dedication that one can hardly still ask of a child can still be asked of a spouse in a craft business. At the same time, this spouse can now have her (always more than his) professional qualities recognized through certified and state-recognized training, and can build her own retirement funds for her old age, whether spent alone or with her spouse.

\section{TRANSLATED ABSTRACTS \\ FRENCH - GERMAN - SPANISH}

Manuela Martini. Quand les travailleurs non rémunérés ont besoin d'un statut légal: les collaborateurs familiaux et le changement des droits du travail dans la France du $X X^{e}$ siècle.

Dans la seconde moitié du vingtième siècle, la petite entreprise familiale perdurait en France. Cette persistance tenait notamment, entre autre, à la part de travail non rétribué de membres de la famille. Dans certaines petites entreprises familiales artisanales et commerciales, le travail non rémunéré de membres de la famille - en particulier des épouses, fils et filles - contribuait tant à la survie de l'entreprise qu'au bien-être de la famille. Sans être statistiquement documenté, de nombreuses sources témoignent de son importance. Bien que les droits sociaux en France soient considérés comme parmi les plus avancés en Europe, le Parlement fut extrêmement lent à définir le statut légal de ces travailleurs familiaux. Ce n'est qu'en 1982 qu'une loi fut finalement adoptée pour attribuer un statut professionnel aux conjoints collaborateurs, et pour leur garantir des avantages de la sécurité sociale. Cet article se concentre sur le processus qui conduisit à redéfinir la démarcation entre le devoir marital d'assistance et le travail au-delà de cette obligation morale et légale, créant ainsi un droit légal qu'il fallait compenser. Deux perspectives empiriques, d'une

92. JORF, Débats parlementaires, Assemblée nationale, Compte rendu intégral, ière séance du jeudi 8 avril I982, pp. 997-1003. 
part une analyse des raisons à l'origine de la position changeante des associations commerciales sur cette question et, d'autre part, une évaluation de l'influence d'anciennes institutions genrées, telles que l'autorité maritale, sur les règles formelles et informelles régulant l'entreprise familiale, permettent d'illustrer ce processus lent et tortueux des droits professionnels des travailleurs familiaux.

\section{Traduction: Christine Krätke-Plard}

Manuela Martini. Wenn unbezablte Arbeiter einen rechtlichen Status benötigen: Familienarbeiter und der Wandel der Arbeitsrechte im Frankreich des 20. Jabrbunderts.

In der zweiten Hälfte des 20. Jahrhunderts hielten sich in Frankreich noch viele kleine Familienunternehmen. Ein wesentlicher Grund für dieses Beharrungsvermögen war der Anteil unbezahlter Arbeit, den Angehörige leisteten, indem sie für den Markt produzierten. Die unbezahlte Arbeit von Familienmitgliedern - insbesondere von Ehegattinnen, Söhnen und Töchtern - trug in einer Reihe von Familienunternehmen in Handwerk und Einzelhandel sowohl zum Überleben des Unternehmens als auch zum Wohlergehen der Familie bei; das belegen zahlreiche Quellen, auch wenn es statistisch nicht dokumentiert ist. Zwar gelten die sozialen Rechte in Frankreich als im europäischen Maßstab besonders ausgeprägt, doch das Parlament hat sich nur sehr schleppend der Aufgabe angenommen, den rechtlichen Status dieser Familienarbeiter zu definieren. Erst 1982 wurde ein Gesetz verabschiedet, das mitarbeitende Ehegattinnen als berufstätig definierte und ein Verfahren festlegte, das es ihnen auf Wunsch ermöglichte, ihre unbezahlte Arbeit zu registrieren, um in den Genuss von Sozialversicherungsleistungen zu kommen. Der Beitrag fokussiert auf die Entwicklung, durch die die Unterscheidung zwischen ehelicher Beistandspflicht und Arbeit, die über diese moralische und rechtliche Verpflichtung hinausgeht, neu bestimmt wurde, wodurch ein Rechtsanspruch auf Vergütung geschaffen wurde. Anhand von zwei empirischen Betrachtungen, einschließlich einer Analyse der Gründe für den Positionswechsel der Gewerkschaften in dieser Frage, aber auch anhand einer Bewertung des Einflusses alteingeführter geschlechtsspezifischer Institutionen wie etwa der Autorität des Ehemannes, wird die langsame und gewundene Entwicklung veranschaulicht, an deren Ausgang Berufsrechte für Familienangehörige standen.

Übersetzung: Max Henninger

Manuela Martini. Cuando los trabajadores sin sueldo necesitan un estatus legal: los trabajadores familiares y los cambios en los derechos laborales en Francia durante el siglo $X X$.

A lo largo de la segunda mitad de siglo veinte los pequeños negocios familiares todavía ocupaban un lugar a tener en cuenta en Francia. Una de las importantes razones para esta resiliencia reside en el trabajo compartido no remunerado realizado por parientes a la hora de producir para el mercado. El trabajo no remunerado de los miembros de la unidad familiar en el ámbito de diversos oficios y negocios comerciales familiares - en 
particular aquel realizado por las esposas, los hijos y las hijas - ha contribuido tanto a la supervivencia del negocio como al bienestar de la familia, tal como numerosas fuentes permiten corroborar, aunque este aspecto no se encuentra estadísticamente documentado. Aunque los derechos sociales en Francia están considerados por ser unos de los más avanzados en Europa, el Parlamento ha sido lento de forma extrema a la hora de definir el estatus legal de estos trabajadores familiares. No ha sido hasta el año 1982 cuando se ha aprobado una ley por la que se confiere un estatus ocupacional a las esposas que colaboran en el negocio familiar y define un procedimiento por el que de forma opcional se puede registrar este tipo de trabajo no remunerado y así acogerse a los beneficios que proporciona el sistema de seguridad social. Este artículo se centra en el proceso que ha llevado a establecer una nueva definición de la demarcación entre el deber marital de colaborar y el trabajo realizado que supera esta obligación moral y legal y, por consiguiente, a crear un derecho legal para compensar dicha obligación. Se plantean dos perspectivas empíricas que implican, de un lado, un análisis de las razones por las que las organizaciones sindicales han variado de posición a este respecto y, de otro, una estimación de la influencia que ciertas instituciones con un marcado y ancestral acento de género, tal como podríamos señalar en la autoridad marital, han tenido en las leyes tanto formales como informales que han regulado los negocios de tipo familiar. Perspectivas que permiten ilustrar este lento y tortuoso proceso de los derechos ocupacionales para los trabajadores familiares.

Traducción: Vicent Sanz Rozalén 